\title{
Research of Relationship Between Innovation Investment and Performance in Innovative Enterprises Under the Innovation-Driven Background
}

\author{
Cui GUO, Feng-yan WANG
}

Shandong Women's University, Jinan, Shandong, China

Keywords: Innovative Enterprises; Innovation Investment; Performance.

\begin{abstract}
The development of the economy can not be separated from the innovation of the enterprises. In order to enhance the innovation vitality and development power of the enterprises, the State advocates that enterprises should form a science and technology innovation system with in-depth integration of production, education and research. Based on the innovation-driven background, this paper selects the listed innovative enterprises published by the country as the research object. This paper uses $R \& D$ expenditure and technical personnel investment to measure the innovation investment of the enterprises, and studies its influence on the performance of enterprises. The results show that the more funds invested by enterprises in research and development, the higher the exchange returns, the better the performance of enterprises.
\end{abstract}

\section{Introduction}

The report of the $19^{\text {th }}$ National Congress of the Communist Party of China clearly pointed out that the Internet should serve the real economy and it is necessary to combine artificial intelligence with the real economy so as to achieve the innovation-lead and innovation-driven development strategy to cultivate new growth points and form new momentum for the enterprises. The enterprises should deepen the reform of the scientific and technological system, establish the technological innovation system with in-depth integration of production, education and research, increase the investment in scientific and technological personnel and scientific research, and promote the transformation of scientific and technological achievements. At the second meeting of the Central Financial and Economic Commission, it was also mentioned that we should improve the ability of key core technology innovation to provide a strong scientific and technological guarantee for China's development.

Since 2006, the Ministry of Science and Technology, the SASAC and the All-China Federation of Trade Unions have begun to carry out pilot projects for innovative enterprises. In 2008, three departments carried out evaluation and acceptance work for pilot enterprises. So far, 356 state-level innovative enterprises have been approved. Different from other enterprises, these innovative enterprises, in accordance with the national innovation strategy policy, enhance innovation vitality, push forward the requirements of innovation-driven development, adjust the industrial structure, actively undertake major innovation tasks, increase investment in scientific and technological personnel and scientific research, and develop new patents and products.

At present, the research about innovative enterprises mainly focuses on two perspectives:

One is to study the list of innovative (pilot) enterprises published by the State. Wei-Yu DUAN, et al. (2012) took the listed innovative enterprises as the research object and used factor analysis method to calculate the growth scores. The results shows that debt ratio and short-term debt restrain the growth of enterprise, but long-term debt promote the growth of the enterprise. Guo-Ai GU, et al. (2012) researched the impact of innovative enterprises' $R \& D$ expenditure on patent capability by questionnaires. Chi-Dong ZHANG (2013) summarized the characteristics of different types of innovative pilot enterprises by questionnaires. Rui-Zhi PANG, et al. (2014) investigated the relationship between the government and enterprise and the ownership of the innovative enterprises, measured the R\&D by the proportion of scientific and technological personnel and the proportion of 
R\&D expenditure, and studied the influence of the relationship between government and enterprise and R\&D on the innovation performance. The results showed that the advantages of the relationship between government and enterprise have not been transformed into the motive force of innovation performance, but R\&D investment promoted innovation performance. Xi-Gen GUO (2016) found that innovative pilot enterprises concentrated in the high level of urban areas while the size of city, the level of financing, market openness and other factors affected its distribution. Wei LIU, et al. (2016) found R\&D investment of listed innovative enterprises expanded the scale of exports.

Another is to study the GEM listed companies as representatives of innovative enterprises. Jian ZHOU, et al. (2012) studied the impact of corporate governance structure on performance in the GEM listed companies. The results showed that higher executive compensation brought good corporate performance, and the introduce of independent directors alleviated the problem of excessive power of actual controller to promote enterprise performance. Yong WANG (2015) divided the financial performance of the GEM listed companies into four aspects of revenue, operation, debt service and growth, and studies the impact of scientific and technological innovation investment on the performance of these four aspects. The results showed that the investment of scientific and technological innovation promoted the performance. Wei-Jun ZHENG (2016) took the innovation investment as the intermediary variable to study its influence on the enterprise performance in the GEM listed companies. The empirical results showed that there was a certain intermediary role. Chang LIU (2017) thought that the electronic information industry was an innovative industry and took the listed companies of A share electronic information industry as research objects. It showed that $R \& D$ expenditure had a lagging effect on financial performance.

This paper studies the impact of innovation investment on the performance of listed state-level innovative enterprises drawing on previous research results.

\section{Research Design}

\subsection{Research Hypothesis}

The earliest idea of innovation was put forward by J. A. Joseph Alois Schum Peter. He thought that enterprises innovation should change the original mode of operation, introduce new production elements, develop new products and new markets, and engage in production in a new form. The theory of endogenous growth believes that technological progress is the endogenous force of economic growth, and technological progress relies on innovation to create technological achievements which can be transformed into economic benefit in the operation and production. The economic momentum generated by innovation is not just a short-term effect. In effect, after putting the new product into the market, it will be beneficial to long-term production and operation. Combined with related theories, this paper put forward the following two hypotheses.

Hypothesis 1. Innovation investment is conducive to promoting enterprises performance.

Hypothesis 2. The effect of innovation investment on enterprises performance has certain lag.

\subsection{Sample Selection and Data Sources}

Taking into account the availability of the data, this paper selects the listed national innovation enterprises as the research objects, and matches the list of national innovation enterprises published by the Ministry of Science and Technology, the SASAC and the All-China Federation of Trade Unions with the list of listed companies in Shanghai and Shenzhen A shares. After deleting abnormal data, the paper gets 143 listed national innovation enterprises. This paper collects and sorts out the data of these enterprises from 2015 to 2016 with the help of CSMAR database, Shanghai and Shenzhen Stock Exchange website and Juchao Consulting website.

\subsection{Variable Setting}

Dependent Variable. After the enterprises increase the innovation investment, it will influence the net profit through production sales and other links, and increase the performance of the enterprises. 
This paper calculates rate of return on equity to measure the enterprise performance.

Independent Variable. Enterprises increase innovation investment and introduce new production factors including labor and capital. Therefore, this paper selects R\&D expenditure and the number of technical personnel to measure the innovation investment of enterprises. Considering the disadvantages of absolute number, this paper calculates $R \& D$ expenditure ratio and technical personnel ratio to replace absolute index.

Control Variable. The selection process of innovative enterprises mainly considers continuous innovation ability and the core technology. It is selected from state-owned enterprises, high and new technology enterprises and other innovative enterprises. Therefore, the scale and the capital structure of enterprises in the list of innovative enterprises are different. So this paper selects enterprise scale and asset liability ratio to control.

To sum up, the variable definitions are shown in Table 1.

Table 1. Variable Definition Table

\begin{tabular}{lll}
\hline \multicolumn{1}{c}{ Variable Name } & \multicolumn{1}{c}{ Index } & \multicolumn{1}{c}{ Calculation Formula } \\
\hline Dependent Variable- & Rate of Return on Equity & Net Profit/Owner's Equity \\
Enterprise Performance & (ROE) & \\
Independent Variables- & R\&D Expenditure Ratio (RD) & R\&D Expenditure/Business Income \\
Innovation Investment & Technical Personnel Ratio & Number of Technicians/Total \\
& (TP) & Number of Workers \\
Control Variables & Enterprise Scale (Size) & Natural Logarithm of Total Asset \\
& Asset-Liability Ratio (Debt) & Liability/Asset \\
\hline
\end{tabular}

\subsection{Model Constructing}

In order to verify the impact of innovative investment on enterprise performance, this paper constructs the following models:

$$
\mathrm{ROE}=\alpha_{0}+\alpha_{1} \mathrm{RD}+\alpha_{2} \mathrm{TP}+\alpha_{3} \text { Size }+\alpha_{4} \text { Debt }+\varepsilon .
$$

Among them, $\alpha_{0}$ represents intercept, $\alpha_{1-4}$ represents coefficient, and $\varepsilon$ represents residuals.

\section{Empirical Analysis}

\subsection{Descriptive Statistics}

In order to understand the basic situations of the listed national innovative enterprises, this paper make a descriptive statistics using Stata, as shown in Table 2.

Table 2. Descriptive Statistics Table

\begin{tabular}{llllll}
\hline Index & Sample Number & Minimum & Maximum & Mean & Standard Deviation \\
\hline ROE & 143 & -1.8344 & 0.2904 & 0.0358 & 0.1888 \\
RD & 143 & 0.0003 & 0.8856 & 0.0511 & 0.0808 \\
TP & 143 & 0.0004 & 0.8899 & 0.1548 & 0.1374 \\
Size & 143 & 8.7835 & 11.8535 & 10.0745 & 0.6547 \\
Debt & 143 & 0.0955 & 0.9597 & 0.4835 & 0.1869 \\
\hline
\end{tabular}

It can be seen from the table that the performance of listed national innovative enterprises varies greatly, and some enterprises have negative net profit. There is also a certain gap between the enterprises in innovation. The average values of $R \& D$ expenditure ratio and technical personnel ratio are 0.0511 and 0.1548 respectively. The average $R \& D$ expenditure ratio just reaches the internationally recognized standard, which shows that the innovation enterprises still have a large room for growth in the innovation-driven development. Through the Size index, we can see that there is a certain gap between the scale of enterprises. According to Debt index, the average of asset- 
liability among enterprises is 0.4835 , which is fit in with the appropriate level of $40 \%-60 \%$.

\subsection{The Analysis of Regressions}

A. Regression Analysis between Innovation Investment and Current Enterprise Performance

Table 3. Regression Results of Innovation Investment and Current Enterprise Performance

\begin{tabular}{l|l|l|l|l|ll}
\hline ROE & Coef. & Std.err. & $\mathrm{t}$ & $\mathrm{P}>|\mathrm{t}|$ & {$[95 \%$ Conf. Interval] } \\
\hline TP & .0013 & .0011 & 1.19 & 0.237 & -.0008445 & .0033798 \\
\hline RD & .0040 & .0018 & 2.17 & 0.031 & .000363 & .0076511 \\
\hline Size & .1174 & .0268 & 4.38 & 0.000 & .0644029 & .1703639 \\
\hline Debt & -.5185 & .0934 & -5.55 & 0.000 & -.703208 & -.3337726 \\
\hline cons & -.9327 & .2521 & -3.70 & 0.000 & -1.431199 & -.4341008 \\
\hline Prob $>F=0.0000$
\end{tabular}

According to the regression results, it can be seen that the regression coefficient of the technical personnel ratio is 0.0013 and the sig value is 0.237 . It shows that the introduction of innovative technical personnel will increase the enterprise performance, but the relationship is not significant. The regression coefficient of $R \& D$ expenditure ratio is 0.0040 , and the sig value is 0.031 . It shows that increasing the investment intensity to the R\&D expenditure will bring higher performance. At the same time, this relationship has passed the significant test of 5\%, which supports Hypothesis 1 . The regression coefficient of enterprise scale is 0.1174 and the value of sig is 0.000 . It shows that the larger the scale of the enterprises, the more powerful it is to carry out innovative development and production management, which is beneficial to improving enterprises performance. The regression coefficient of asset-liability ratio is -0.5185 and sig value is 0.000 , which indicates that the higher the debt level, the higher the debt cost, and thus the enterprise performance will be reduced.

\section{B. Regression Analysis between Innovation Investment and Lagged Enterprise} Performance.

Table 4. Regression Results of Innovation Investment and Lagged Enterprise Performance

\begin{tabular}{l|l|l|l|l|ll}
\hline ROE & Coef. & Std.err. & $\mathrm{t}$ & $\mathrm{P}>|\mathrm{t}|$ & \multicolumn{2}{|c}{ 95\% Conf. Interval $]$} \\
\hline TP & .0006 & .0011 & 0.50 & 0.616 & -.0016361 & .002752 \\
\hline RD & .0038 & .0019 & 2.00 & 0.047 & .0000481 & .0076188 \\
\hline Size & .1117 & .0278 & 4.01 & 0.000 & .0566734 & .1667431 \\
\hline Debt & -.5170 & .0970 & -5.33 & 0.000 & -.7089244 & -.3251643 \\
\hline cons & -.8638 & .2619 & -3.30 & 0.001 & -1.381645 & -.3458846 \\
\hline
\end{tabular}

$\bar{P}$ rob $>F=0.0000$

In order to verify whether the enterprise's innovation investment has an impact on future performance, the innovation investment data of 2015 and the performance data of the lag phase of the enterprise are regressed in this paper. From the regression results of Table 4, it can be seen that the regression coefficient of technical personnel ratio is also not passed the significant test, and the regression coefficient is very small which indicates the correlation are weak. The coefficient of R\&D expenditure ratio is 0.0038 and passes the significance test, which is consistent with the expected hypothesis. It indicates that the increase of innovation investment will have a certain degree of influence on the performance of the future. The regression results of enterprise scale and assetliability ratio are similar to the results of current period.

\section{Conclusion and Suggestion}

\subsection{Conclusion}

Under the guidance of the central policy of the party, the listed national innovation enterprises have 
begun to pay attention to innovation investment, but the investment is not enough. At the same time, there is a certain gap between the enterprises' innovation progress.

The increase of the investment in technical personnel and $R \& D$ expenditure by the national innovative enterprises will increase the innovation and competitiveness of the products, enhance the sales revenue and profitability, at the same time, it can accelerate the business efficiency of the enterprises, and ultimately improve the performance and long-term development of the enterprise.

\subsection{Suggestions}

Pay attention to improve the quality of technical personnel. From the empirical results, we can see that the correlation coefficient of the technical personnel ratio and the enterprise performance is relatively low and has not passed the significant test. The main reason is that the technical personnel introduced by the national innovative enterprises have the advantage in the initial education, knowledge level and so on, but they don't do their jobs effectively limited by training and R\&D investment after entering the job position. Therefore, the national innovative enterprises should pay attention to the overall quality of the introduction of technical personnel, reduce the quantity, increase the strength of training and academic exchanges, and fully mobilize the enthusiasm of the technicians.

Set up special funds for innovation investment. It can be seen from the empirical results that there is a certain gap between the national innovative enterprises in terms of innovation investment, and the amount of funds is limited by the operation of the enterprises. Therefore, the innovative enterprises should actively use the convenience of the national policy to facilitate the financing, set up innovative investment funds, and ensure the number of innovative investment funds to use for R\&D and technological innovation of enterprises.

\section{Acknowledgement}

This research was financially supported by the Shandong humanities and social sciences research projects issues "Research on innovation performance evaluation of innovative enterprises under the background of innovation driven (Grant No. J17RB120)" and Youth research project of Shangdong Women's University issues "Research on the relationship between corporate innovation investment, social responsibility and financial performance (Grant No. 2017YB04)".

\section{References}

[1] Wei-Yu DUAN, Ping SHI, Jian-Hong TAO, Study on the Relationship Between Debt Structure and Growth of Innovative Enterprises-An Empirical Analysis Based on Listed Companies in China[J]. FORECASTING, 2012, 31 (05): 34-39+46.

[2] Rui-Zhi PANG, Wen-Wen SHI, Ming-Lei DING, Conjunction of Politics and Enterprises, Research \& Development and Innovation Performance: Based on the Data of 426 Innovative Enterprises [J]. Modern Economic Science, 2014, 36 (01): 55-62+126.

[3] Wei LIU, Gong-Li LUO, Innovative Enterprise's R\&D and Export-Experimental Analysis Based on 60 Listed Companies' Panel Data in China [J]. China Science and Technology Forum, 2016, (07): 73-78.

[4] Jian ZHOU, Peng-Fei WANG, Wen-Jia LI, Su-Rong CHEN, Research of Relationship Between Corporate Governance Structure and Performance in Innovative Enterprises-Based on Empirical Evidence of Companies Listed on China's GEM [J]. Research on Economics and Management, 2012, (04): 106-115. 